\title{
Production and optimization of extracellular alkaline protease from halotolerant chromate resistant Bacillus circulans isolated from Tannery solid waste
}

\author{
TUHINA VERMA* AND SWATI AGARWAL
}

Department of Microbiology, Dr. Ram Manohar Lohia Avadh University, FAIZABAD (U.P.) INDIA

\section{ARITCLE INFO}

Received : 25.01 .2016

Revised : 28.02 .2016

Accepted : 09.03.2016

KEY WORDS :

Bacillus circulans, Halotolerant, Alkaline protease, Chromate resistant, Tannery

*Corresponding author:

Email: tuhinaverma19@gmail.com

\begin{abstract}
Halotolerant alkaline proteases are of great interest because of their high proteolytic activity and stability under alkaline and high saline environment. These enzymes have extensive applications in industries like laundry detergents, pharmaceutical, food, leather and feather processing and proteinaceous waste bioremediation. Keeping it in view, the study was aimed to isolate chromate resistant, haloalkliphilic protease producing Bacillus circulans bacteria from the discharged tannery solid waste. A total of seven bacterial strains were isolated on selective milk agar plates ( $\mathrm{pH}$ 8.0-9.0) from tannery solid waste on the basis of different colony morphology and higher tolerance capacity for chromate and $\mathrm{NaCl}$. These strains exhibited variable alkaline protease activity and were tolerant to different concentration of both chromate $(200-1300 \mu \mathrm{g} / \mathrm{ml})$ and $\mathrm{NaCl}(1-9 \%)$. Out of seven, one strain TVD-5 was interestingly tolerant to high concentration of $\mathrm{Cr}(\mathrm{VI})(1300 \mu \mathrm{g} / \mathrm{ml})$ and $\mathrm{NaCl}(8.0 \%)$ and exhibited vibrant clear zone diameter between $(13-30 \mathrm{~mm})$ on 1.0 per cent skim milk agar medium at $\mathrm{pH} 9.0$ after $28 \mathrm{~h}$ incubation. This strain produced maximum protease of 390 Units/ ml during early stationary phase after $36 \mathrm{~h}$ of growth. The enzyme exhibited its optimal activity at $\mathrm{pH}$ 9.0, temperature $35^{\circ} \mathrm{C}$ and 8.0 per cent salinity, whereas, significantly active and stable in broad $\mathrm{pH}(7.5-11.0)$ and temperature $\left(25-45^{\circ} \mathrm{C}\right)$ range and at $\mathrm{NaCl}$ concentrations ranging from 7.0 to 13.0 per cent. This bacterium may potentially be useful for simultaneous bioremediation of $\mathrm{Cr}(\mathrm{VI})$ containing wastes in the environment. Also, the proteases of this study may have many applications in different industries and environmental bioremediation.
\end{abstract}

How to view point the article : Verma, Tuhina and Agarwal, Swati (2016). Production and optimization of extracellular alkaline protease from halotolerant chromate resistant Bacillus circulans isolated from Tannery solid waste. Internat. J. Plant Protec., 9(1) : 211-218. 